\title{
VIEWPOINT What contributions are invasive plant species making to ecosystem services?
}

\author{
Stephen L. Young
}

nvasive plant species can establish in diverse environments, and, with the increase in human mobility, they are no longer restricted to isolated pockets in remote parts of the world. Cheatgrass (Bromus tectorum L.) in rangelands, purple loosestrife (Lythrum salicaria L.) in wetlands, and tamarisk (Tamarix spp.) in riparian areas are examples of invasive plant species that are common to the United States and can be found in monocultures and patches covering many thousands of hectares. Across the world, invasive plant species like water hyacinth (Eichhornia crassipes), cogon grass (Imperata cylindrica), and mile-a-minute weed (Persicaria perfoliata L.) have choked waterways, altered fire regimes, or caused the abandonment of farmland due to their dominating and persistent characteristics.

Clearly, the effects of invasive plant species have reached global scales and their related costs have been estimated in the billions of dollars (Pejchar and Mooney 2009). While the control of invasive plant species is warranted in many natural and man-made environments, these species do provide services to these ecosystems, which have yet to be quantified on a range of scales.

Ecosystem services are the benefits obtained from ecosystems and include provisional (e.g., food, water, fiber), regulating (e.g., carbon sequestration, waste decomposition, air purification, erosion), supporting (e.g., nutrient dispersal and cycling, primary productivity) and cultural (e.g., religious, recreation) categories (MEA 2005). The estimated value of the services that these ecosystems provide is now between $\$ 16$ and $\$ 54$ trillion per year.

The quantification of ecosystem services first requires their identification in relation

Stephen L. Young is weed ecologist and assistant professor at the West Central Research and Extension Center, University of NebraskaLincoln, North Platte, Nebraska. to provisional, regulating, supporting, and cultural categories. For example, annual cost of irrigation water lost to tamarisk in the Ogallala region of the US Midwest has been estimated at $\$ 2.8$ to $\$ 7.9$ billion (Zavaleta 2000). In the Great Basin, cheatgrass has established in rangelands, reducing forage quality and increasing losses associated with fire control and rehabilitation efforts to estimates between $\$ 0.1$ million and \$20 million (Duncan et al. 2004). Monocultures of yellow starthistle (Centaurea solstitialis L.), giant reed (Arundo donax L.), and kudzu (Pueraria montana var. lobata) have displaced many locally occurring native species with an unknown price tag, but a loss, nonetheless, for generations to come.

While the deleterious impacts from invasive species on ecosystem services have begun to be quantified, contributions, on the contrary, are less known. In many cases, a trade-off exists between the negative (e.g., loss of diversity) and positive (e.g., erosion control) effects on services provided by invasive plant species in an ecosystem. In the case of tamarisk along the Colorado River, the infestation is so great that native plants had been completely choked out. At the same time, songbirds, rare to the area, have developed nesting sites in the tamarisk, which has put local officials in a quandary as to which is the higher priority.

The identification and monitoring of the most aggressive and largest infestations of invasive plant populations have been possible using aerial photography (e.g., remote sensing, satellite tracking). With hyperspectral cameras and near-infrared imagery, photographs can be interpreted with GIS software and other spatial analyses tools. The distribution of invasive plant species on the landscape can now be correlated with specific geographic features (e.g., slope, soil type) in order to predict movement and aid in control efforts (Hoffman et al. 2008). Similarly, the identification of ecosystem services on the landscape would be useful for correlating with the distribution of invasive plant species populations.

The establishment of national and international policies for regulating practices that contribute to ecosystem services has yet to be fully imposed due to much uncertainty (USEPA 2007; MEA 2005). The cost of a lost or existing ecosystem service that provides for human well-being (e.g., clean air, drinking water) is unknown. While some services may now be provided using technological capabilities, the natural function of an ecosystem service is often the most economical. Unfortunately, ecosystem services are still viewed by many as free and limitless, without their full value being taken into account. Until this viewpoint changes, the implementation of policies to reduce the impacts from humans on ecosystem services, including invasive plant species management, is somewhat futile.

In quantifying ecosystem services, two objectives of the US Environmental Protection Agency (USEPA 2007) standout in relation to invasive plant species: (1) identify knowledge gaps in the processes underlying ecosystem services and (2) evaluate benefits of ecosystem services and trade-offs among management actions that affect these services. While the number of hectares of invasive plant species continues to increase, in some cases rapidly (Duncan et al. 2004), information on their contribution to ecosystem services is severely lacking. Once the value of ecosystem services is determined, the value of managing invasive plant species can be fully realized and better decisions can be made regarding the implementation of policies.

Invasive plant species' contribution to ecosystem services is controversial because of the mostly negative relationship that these species have with the native or desirable plant species. However, their continued dominance in many regions warrants a more thorough evaluation of their impact, both positive and negative, 
on the ecosystem (Hershner and Havens 2008). The use of technology to identify and quantify ecosystem services across the landscape will help in determining their value and the management strategy policies, particularly in areas that include invasive plant species.

\section{REFERENCES}

Duncan, C.A, J.J. Jachetta, M.L. Brown, V.F. Carrithers, J.K. Clark, J.M. DiTomaso, R.G. Lym, K.C. McDaniel, M.J. Renz, and P.M. Rice. 2004. Assessing the economic, environmental, and societal losses from invasive plants on rangelands and wildlands. Weed Technology 18:1411-1416.

Hershner, C., and K.J. Havens. 2008. Managing invasive aquatic plants in a changing system: strategic consideration of ecosystem services. Conservation Biology 22(3):544-550.

Hoffman, J.D., S. Narumalani, D.R. Mishra, P. Merani, and R.G. Wilson. 2008. Predicting potential occurrence and spread of invasive plant species along the North Platte River, Nebraska. Invasive Plant Science and Management 1:359-367.

MEA (Millennium Ecosystem Assessment). 2005. Ecosystems and human well being: synthesis. Washington, DC: Island Press.

Pejchar, L., and H.A. Mooney. 2009. Invasive species, ecosystem services and human well-being. Trends in Ecology and Evolution 24(9):497-504.

USEPA (US Environmental Protection Agency). 2007. Willamette ecosystem services project. Report \#600 R-07 057. US Environmental Protection Agency.

Zavaleta, E. 2000.The economic value of controlling an invasive shrub. Ambio 29(8):462-467. 